\title{
A cross sectional study of chemical industry workers with occupational exposure to persulphates
}

Rolf Merget, Axel Buenemann, Rupprecht Kulzer, Anja Rueckmann, Rolf Breitstadt, Annegret Kniffka, Herbert Kratisch, Reinhard Vormberg, Gerhard Schultze-Werninghaus

Division of

Pneumonology and

Allergology,

Department of

Internal Medicine,

University Hospital

Bergmannsheil

R Merget

A Buenemann

G Schultze-Werninghaus

Department of

Medical Computer

Science, Biometrics

and Epidemiology,

Medical Division,

Ruhr-University,

Bochum

A Rueckmann

Degussa AG, Medical

Department,

Frankfurt am Main

and Rheinfelden,

Germany

R Kulzer

R Breitstadt

A Kniffka

Department for

Analytical Chemistry,

Frankfurt am Main

and Rheinfelden,

Germany

H Kratisch

$R$ Vormberg

Correspondence to:

Dr Rolf Merget,

Berufsgenossenschaftliche

Kliniken, Bergmannsheil-

Universitätsklinik,

Medizinische Klinik und

Medizinische Klinik
Poliklinik, Abteilung

Poliklinik, Abteilung

Pneumologie und

Allergologie, Buerkle-de-
Camp-Platz 1, D-44789

Bochum, Germany.

Accepted 16 January 1996

\begin{abstract}
Objectives-Hair bleaches containing persulphates have been identified as the cause of occupational asthma in hairdressers. Also employees in persulphate production with occupational asthma have been described. It was the aim of this study to give an estimate of the prevalence of asthma due to persulphates in chemical workers with exposure to ammonium and sodium persulphate.

Methods-A cross sectional study was performed in 32 of 33 employees of a persulphate producing chemical plant. Eighteen of 23 workmen from the same plant with no exposure to persulphates were taken as controls. Also, information was collected from medical records of the seven subjects who had left the persulphate production for medical reasons since 1971. Data were recalled by a questionnaire, skin prick tests were performed with five environmental allergens, and ammonium and sodium persulphate (80 $\mathrm{mg} / \mathrm{ml}$ ). Specific immunoglobulin E (IgE) to the same environmental allergens as in the skin test, and total IgE were measured. Lung function and bronchial responsiveness to histamine were assessed by standard procedures. Workplace concentrations of ammonium and sodium persulphate were estimated by area and personal monitoring. The amount of persulphate was analysed as sulphur by inductively coupled plasma emission spectrometry.
\end{abstract}

Results-Work related rhinitis was reported by one subject with exposure to persulphates, conjunctivitis and bronchitis were reportedly related to work by two controls. There were no cutaneous reactions to persulphates in either group. Four non-atopic subjects exposed to persulphates, and two controls, one atopic and one non-atopic, were considered to be hyperresponsive to histamine. Three subjects exposed to persulphates with bronchial hyperresponsiveness (provocation dose of histamine causing a $15 \%$ fall in forced expiratory volume in one second $\left.\left(\mathrm{PD}_{15} \mathrm{FEV}_{1}\right) \leqslant 1 \mathrm{mg}\right)$ did not show variability in peak expiratory flow of $\geqslant 20 \%$, the rest refused peak flow measurements. None of the variables showed significant differences between the groups $(P>0.05)$. Six of the exworkers left because of work related contact dermatitis. Mean values for workplace concentrations of ammonium and sodium persulphate within the bagging plant were below $1 \mathrm{mg} / \mathrm{m}^{3}$, and the maximal concentrations were $1.4 \mathrm{mg} / \mathrm{m}^{3}$ and $3.6 \mathrm{mg} / \mathrm{m}^{3}$, respectively. Conclusion-Exposure to workplace concentrations of ammonium and sodium persulphate of about $1 \mathrm{mg} / \mathrm{m}^{3}$ in this chemical plant was not associated with a risk of occupational asthma.

(Occup Environ Med 1996;53:422-426)

Keywords: persulphates; asthma; cross sectional study

Occupational asthma due to persulphates has been described in hairdressers ${ }^{1-3}$ and persulphate production workers in the chemical industry. ${ }^{4}$ Although there are numerous case reports, only one cross sectional study in a hairdressing salon has been published. ${ }^{5}$ In that study, four of 23 employees were considered to have occupational asthma due to persulphates. The diagnosis was established by bleach powder inhalation (14 subjects were tested), but no control group was included. The reaction pattern was a late asthmatic reaction in all positive cases, and only one of the 14 subjects showed a small skin prick test reaction to persulphates.

Skin tests, performed as scratch or patch tests, as well as bronchial challenge tests have been used as indicators of persulphate sensitisation. Bronchial challenge tests have been performed with bleach powders containing persulphates in simulated occupational type exposure tests in most cases. $^{1-35}$ If positive bronchial challenge tests to any material containing persulphates were taken as indicative of persulphate asthma, subjects with both negative $^{15}$ or positive ${ }^{23}$ prick test reactions were identified. Thus the skin prick test to persulphates seems to be insensitive to asthma induced by persulphates. It was the aim of this study to find the frequency of immediate type sensitisations to persulphates; and to give an estimate of the prevalence of symptoms, lung function impairment, and bronchial hyperresponsiveness in a group of chemical workers with supposedly high occupational exposure to persulphates.

Methods

SUBJECTS

Sixty nine people had been employed in per- 
sulphate production since 1971 . Thirty six of them had left the workplace before the cross sectional examination. From the medical records of the medical department of the plant, seven subjects left because of suspected allergy to persulphates, the rest for technical reasons. We examined 32 out of 33 present employees ( 31 male, one female) of the persulphate producing division of the plant. One subject refused to be examined. Six subjects did not allow the histamine challenge. Twenty three workmen without any contact with persulphates were recruited as controls. These controls worked in different areas of the plant and reported qualitatively and quantitatively varying exposure to irritants, mainly welding fumes. Eighteen out of 23 control workmen participated in the study; three refused to have the tests, two were not available, and three people refused the inhalation of histamine. One of four subjects exposed to persulphates with bronchial hyperresponsiveness refused peak flow measurements.

\section{EXWORKERS}

Information concerning subjects who had left work in the persulphate division before the present study was collected from both the administration and the medical department plants'. If subjects had to leave for medical reasons, symptoms and signs were documented in the medical records. Thirty six subjects had left the persulphate workshop since 1971 , among them seven workers left for medical reasons. Six of these left because of work related skin disease without symptoms of asthma, the other had complained of asthma. Immunological assessments or lung function tests for these workers were not available.

\section{RECALLED DATA}

Age and occupational exposure time were recorded. Further data were assessed by questionnaire: (a) symptoms of asthma, rhinitis, conjunctivitis, dermatitis, or bronchitis occurring during employment; $(b)$ relation of these symptoms to work; (c) personal and family history of asthma or allergy mediated by immunoglobulin E (IgE), mostly pollinosis or mite allergy confirmed by a physician before employment; $(d)$ wheeze during the previous 12 months; (e) cough at night during the previous 12 months; $(f)$ shortness of breath at night during the previous 12 months; $(g)$ smoking habit (exsmoker, non-smoker, smoker); (h) personal estimate of persulphate exposure (period of occupation at the bagging plant compared with the other workers (low, moderate, high)).

\section{SKIN PRICK TEST}

Skin prick tests were performed with common environmental allergens (cat dander, grass, and birch pollens, Dermatophagoides pteronyssinus, and Alternaria tenuis (Allergopharma, Reinbek, Germany)). Skin prick tests with persulphates were performed with $80 \mathrm{mg} / \mathrm{ml}$ solutions of sodium persulphate $(\mathrm{pH} 3.9)$ and ammonium persulphate ( $\mathrm{pH} 3 \cdot 1)$. These solutions were prepared with distilled water, and because of the acidity of the solutions also with phosphate buffer, $\mathrm{pH} \mathrm{7 \cdot 4}$. The solutions were stored for a maximum of three days at $4^{\circ} \mathrm{C}$. Tests with persulphates were performed in duplicate. The reaction was recorded after 15 minutes and 24 hours. Subjects were asked to report any skin reaction between the two readings. A positive reaction was defined as an immediate weal reaction $\geqslant 4 \mathrm{~mm}$, or any reaction after 24 hours.

\section{TOTAL SERUM IGE AND ENZYME}

ALLERGOSORBENT TEST (EAST)

Total IgE was measured with Phadezym PRIST (Pharmacia, Freiburg, Germany). Specific IgE to environmental allergens was measured with Phadezym RAST (Pharmacia). The same allergens were used as in the skin test. Measurements were performed according to the manufacturers' directions. A positive test was defined as $\geqslant$ RAST class $I$.

\section{LUNG FUNCTION}

Forced expiratory volume in one second $\left(\mathrm{FEV}_{1}\right)$, and maximal expiratory flow at $50 \%$ of forced vital capacity $\left(\mathrm{MEF}_{50}\right)$ were measured with a pneumotachograph (CustoVit, CustoMed, Munich, Germany). Measuring conditions and reference values were chosen as described recently. ${ }^{6}$ Peak flow measurements were recorded for two weeks three times daily with a Mini-Wright peak flow meter (Airmed, London) in three persulphate workers with bronchial hyperresponsiveness. Measurements were performed before work, during work (before lunch), and before leaving the plant in the evening during working days, and at the same times during weekends.

\section{BRONCHIAL HYPERRESPONSIVENESS}

Bronchial responsiveness to histamine (Merck, Darmstadt, Germany) was assessed with an $8 \mathrm{mg} / \mathrm{ml}$ solution. It was stored at $4^{\circ} \mathrm{C}$ for not longer than two weeks. The $\mathrm{FEV}_{1}$ was recorded by a dry spirometer (Vitalograph, Hamburg, Germany) before and one minute after $1,2,4,8,16$, and 32 breaths. Inhalation was performed with a jet nebuliser (Inhalierboy, Pari, Starnberg, Germany). The inhalation was stopped when the $\mathrm{FEV}_{1}$ had fallen by $\geqslant 15 \%$ from baseline, or after 32 breaths. No subject used any drug that might alter airway responsiveness. To get a quantitative value for all subjects, bronchial responsiveness was expressed by the slope of a line extending from the origin of the dose-response curve to the last data point. ${ }^{7}$ The cumulative doses of histamine, assessed by weighing the aerosol reservoir before and after each inhalation step, were used for calculation of the slope. Also, the provocation dose of histamine causing a $15 \%$ fall in forced expiratory volume in one second $\left(\mathrm{PD}_{15} \mathrm{FEV}_{1}\right)$ was calculated from the linear curve between the two data points of the cumulative dose-response curve adjacent to the $15 \%$ fall in $\mathrm{FEV}_{1}$ by interpolation with a Hewlett Packard 41C calculator. Bronchial hyperresponsiveness was defined as $\mathrm{PD}_{15} \leqslant 1 \mathrm{mg}$. 
DESCRIPTION AND ASSESSMENT OF WORKPLACE Ammonium persulphate is produced by anodic oxidation of a concentrated ammonium sulphate solution. Sodium persulphate is made by conversion of ammonium persulphate with soda lye. The production is widely automated, relevant exposure being confined to the bagging plant or to rare breakdowns of a production line. The substances are stored in a bunker which is connected to a bagging plant. The weight of the bags are 25 or $50 \mathrm{~kg}$. Area and personal monitoring were performed according to German standards at the bagging plant, but not in the laboratories, control rooms, and operating rooms. Sampling equipment was placed about half a metre from the bag filling station. There is no relevant exposure to irrtants, although occasional exposure to ammonia and sulphur dioxide due to leakage cannot be excluded. Measurements of ammonia and sulphur dioxide were not performed. The workers exposed to persulphates used gloves at the bagging station, but did not use personal protective breathing devices.

Table 1 Workplace concentrations of total dust, ammonium and sodium persulphate (medians (range), $m g / m^{3}$ )

\begin{tabular}{lll}
\hline & Area & Personal \\
\hline Total dust & $0 \cdot 8(0.3-1 \cdot 6)$ & $1 \cdot 2(0 \cdot 8-1 \cdot 8)$ \\
& $(\mathrm{n}=11)$ & $(\mathrm{n}=6)$ \\
Sodium persulphate & $0 \cdot 8(0 \cdot 3-3 \cdot 6)$ & $0.9(0.3-1 \cdot 3)$ \\
& $(\mathrm{n}=9)$ & $(\mathrm{n}=4)$ \\
Ammonium persulphate & $\begin{array}{l}0.2(0 \cdot 1-0.5) \\
(\mathrm{n}=9)\end{array}$ & $\begin{array}{l}0 \cdot 8(0.8-1 \cdot 4) \\
(\mathrm{n}=4)\end{array}$ \\
\hline
\end{tabular}

Table 2 Anamnestic data in subjects with exposure to persulphates $(n=32)$ and controls $(n=18):$ percentage values are percentages of examined subjects

\begin{tabular}{|c|c|c|c|}
\hline & Exposed & Controls & $\begin{array}{l}P \text { values } \\
\text { by } \chi^{2} \text { and } \\
\text { t test }\end{array}$ \\
\hline Age $(y)$ & $43 \pm 10$ & $36 \pm 9$ & $<0.02$ \\
\hline Positive family history $(\%)^{\star}$ & 12 & 0 & NS \\
\hline Symptoms before employment $(\%)^{\star}$ & $12(3) \dagger$ & $22(17)$ & NS (NS) \\
\hline Symptoms during employment (\%) $\ddagger$ & $25(6) \dagger$ & $22(6)$ & NS (NS) \\
\hline Work related symptoms $(\%)$ & 3 & 11 & NS \\
\hline Wheezing during previous 12 months (\%) & 12 & 17 & NS \\
\hline Cough at night during previous 12 months (\%) & 12 & 6 & NS \\
\hline Shortness of breath at night during previous 12 months (\%) & 3 & 6 & NS \\
\hline $\begin{array}{l}\text { Smoking: } \\
\text { Smokers (\%) } \\
\text { Non-smokers (\%) } \\
\text { Exsmokers (\%) }\end{array}$ & $\begin{array}{l}37 \\
47 \\
16\end{array}$ & $\begin{array}{l}44 \\
39 \\
17\end{array}$ & E \\
\hline Duration of exposure (months mean (SD)) & $164(109)$ & $52(80)$ & $<0.0005$ \\
\hline $\begin{array}{l}\text { Personal estimate of persulphate exposure: } \\
\text { Low (\%) } \\
\text { Moderate (\%) } \\
\text { High (\%) }\end{array}$ & $\begin{array}{r}22 \\
69 \\
9\end{array}$ & $\begin{array}{l}0 \\
0 \\
0\end{array}$ & E \\
\hline
\end{tabular}

* Only symptoms suggestive of allergy mediated by IgE or clear asthma; tvalues in parenthesis indicate the percentage of subjects with asthma; ‡symptoms of bronchitis, asthma, rhinitis, conjunctivitis, or dermatitis.

Table 3 Sensitisations to environmental allergens

\begin{tabular}{llll}
\hline & Exposed & Controls & P value \\
\hline Weal $\geqslant 4 \mathrm{~mm}$ with at least one allergen (\%) & 25 & 39 & NS \\
EAST $\geqslant$ class 1 with at least one allergen $(\%)$ & 34 & 33 & NS \\
Wheal > 4mm and EAST $\geqslant$ class 1 with same allergen (\%) & 16 & 28 & NS \\
\hline
\end{tabular}

Footnotes as for table 2 .
Personal sampling was performed with a $\mathrm{Du}$ Pont Alpha 1 pump (flow rate $3.51 / \mathrm{min}$ ) and a dust sampling head (sucking velocity 1.25 $\mathrm{m} / \mathrm{s}$ ) provided with a glass fibre filter (diameter $37 \mathrm{~mm}$, Macherey-Nagel, Dueren, Germany). Area samples were taken with a high volume collector (Gravicon VC25, Stroehlein, Kaarst, Germany) at a flow rate of $22.5 \mathrm{~m}^{3} / \mathrm{h}$ and a sucking velocity of $1.25 \mathrm{~m} / \mathrm{s}$. Total dust was collected on glass fibre filters with a diameter of $150 \mathrm{~mm}$ (Macherey-Nagel). The sampling times varied from three to four hours. The amount of persulphates in the dust was analysed as sulphur by inductively coupled plasma emission spectrometry according to German standard procedures. Table 1 shows the number of measurements.

The bagging plant is clearly the place with the highest concentration of persulphates. As the activities are relatively uniform at the bagging plant the maximal concentrations were considered to reflect peak values. With few exceptions, workers participate in a rotation schedule. Thus, almost all workers were exposed to persulphates at the bagging plant to the same degree and for similar periods of time.

\section{STATISTICAL ANALYSIS}

Arithmetic means (SD) are used unless otherwise stated. Values for total IgE and the dose response slope of histamine were log-transformed for calculations. Percentage values were calculated from the number of tests being performed. Non-smokers and exsmokers were grouped together for calculations. Differences between groups were compared with the $t$ test or $\chi^{2}$ test. P values of $5 \%$ or less were considered to be significant.

\section{Results}

Exposed subjects were older and had been employed for longer than controls (table 2). Other demographic data were not different between groups. Work related symptoms of rhinitis were reported by one subject with exposure to persulphates, and work related conjunctivitis and bronchitis by two controls.

Neither exposed subjects nor controls showed an early or late skin test reaction with persulphates. Sensitisations to environmental allergens as assessed by skin test, EAST, or a combination of both were not different between groups (table 3). Lung function $\left(\mathrm{FEV}_{1}\right.$ and $\left.\mathrm{MEF}_{50}\right)$, total IgE, and the dose response slopes of the histamine challenges were not different between groups (figure). The $\mathrm{FEV}_{1}$ was $<80 \%$ of the predicted value in two subjects exposed to persulphates, and in two controls. Bronchial hyperresponsiveness was present in four (13\%) non-atopic persulphate workers, and in two (11\%) controls, one atopic and one non-atopic. Peak expiratory flow records of three subjects with bronchial hyperresponsiveness and persulphate exposure showed no significant variability and did not show a trend for lower values associated with working periods, the fourth subject refused peak flow recording. 


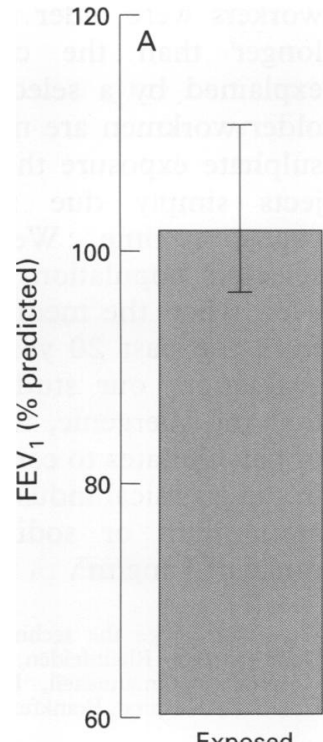

Exposed
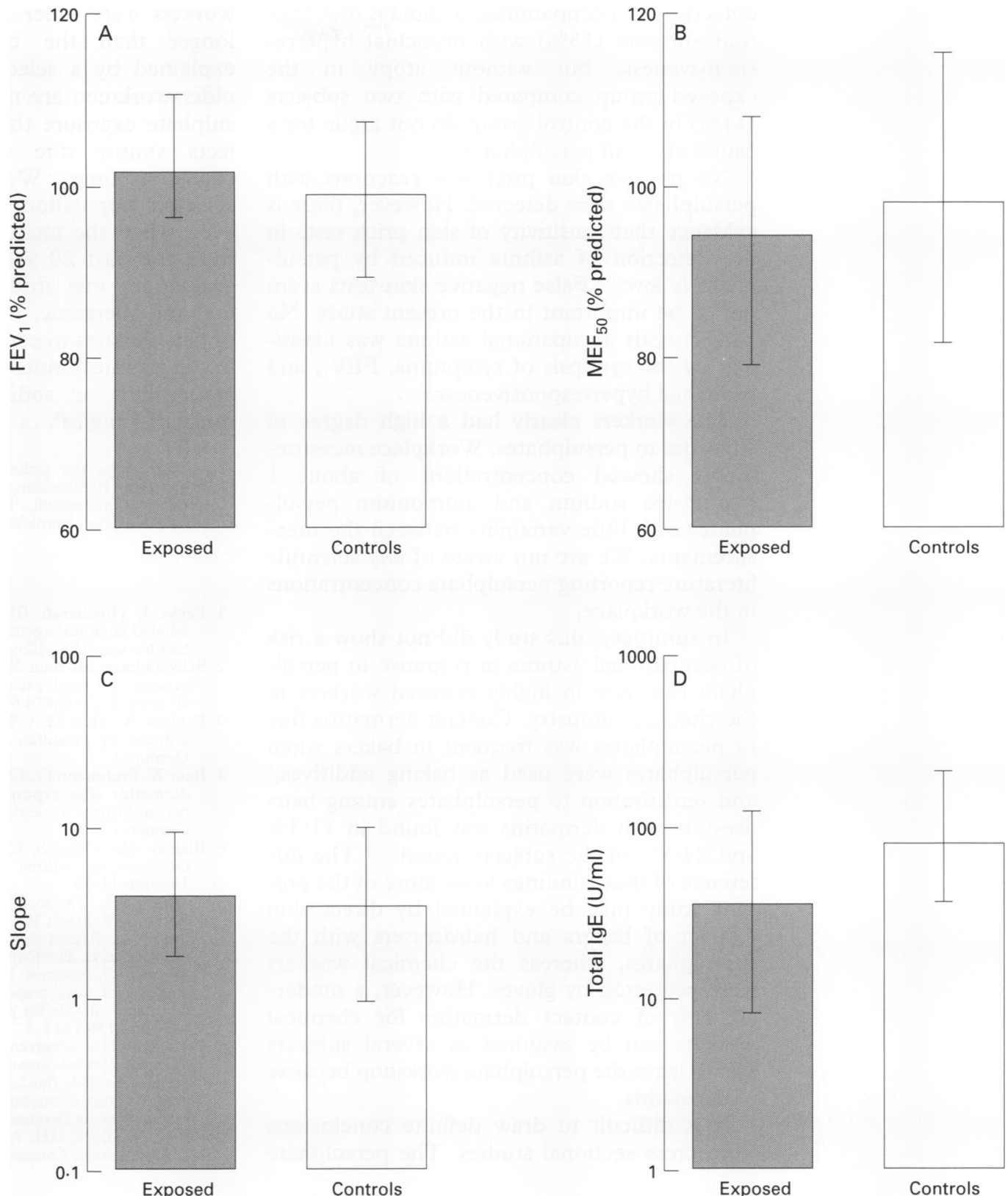

Controls

$A$ and $B F E V_{1}$ and $M E F_{s o}$ (arithmetic means (SDs)); $C$ and $D$ dose response slopes of bronchial challenge tests with histamine and total IgE (geometric means (upper and lower quartiles)). Workers exposed to persulphates $(n=32)$, controls $(n=18)$. There were no differences between groups for all variables $(P>0.05)$.

\section{WORKPLACE EXPOSURE}

There was a good agreement between area and personal samples (table 1). The median concentrations of ammonium and sodium persulphate were below $1 \mathrm{mg} / \mathrm{m}^{3}$, and the peak concentrations were $1.4 \mathrm{mg} / \mathrm{m}^{3}$ and $3.6 \mathrm{mg} / \mathrm{m}^{3}$.

\section{Discussion}

Although persulphates have been identified as the cause of occupational asthma, little is known about the pathophysiological mechanisms as well as the sensitivity and specificity of diagnostic tests. Therefore we used both symptoms and a panel of tests as possible indicators of asthma induced by persulphates.

With the exception of one subject with work related rhinitis, subjects exposed to persulphates reported no work related symptoms. This subject did not show bronchial hyperre- sponsiveness. There is evidence that hyperresponsiveness to non-specific stimuli is present in asthma induced by persulphates. ${ }^{13}$ However, sensitivity of methacholine testing may be lower in this type of asthma as one subject without bronchial hyperresponsiveness but with clear immediate asthma after inhalation of bleach powder has been reported. ${ }^{2}$ The number of subjects with bronchial hyperresponsiveness or reduced $\mathrm{FEV}_{1}$ among exposed workers of our study was low, and subjects with bronchial hyperresponsiveness did not show reductions in peak flow associated with work. Sensitivity of peak flow measurements might have been increased by performing measurements more than three times daily. As the workers were without any further sign of occupational asthma, peak flow recording three times daily was considered to be a compromise between reliable measurements and sensitivity. Specificity of histamine tests for the 
detection of (occupational) asthma is low, thus four subjects (13\%) with bronchial hyperresponsiveness, but without atopy in the exposed group compared with two subjects $(11 \%)$ in the control group do not argue for a causal effect of persulphates.

No positive skin prick test reactions with persulphates were detected. However, there is evidence that sensitivity of skin prick tests in the detection of asthma induced by persulphate is low. ${ }^{15}$ False negative skin tests seem not to be important in the present study. No subject with occupational asthma was identified by the synopsis of symptoms, $\mathrm{FEV}_{1}$, and bronchial hyperresponsiveness.

The workers clearly had a high degree of exposure to persulphates. Workplace measurements showed concentrations of about 1 $\mathrm{mg} / \mathrm{m}^{3}$ for sodium and ammonium persulphate, with little variability between the measurements. We are not aware of any scientific literature reporting persulphate concentrations in the workplace.

In summary, this study did not show a risk of occupational asthma in response to persulphate exposure in highly exposed workers in the chemical industry. Contact dermatitis due to persulphates was frequent in bakers when persulphates were used as baking additives, ${ }^{8}$ and sensitisation to persulphates among hairdressers with dermatitis was found in $11.3 \%$ and $24.5 \%$ of the subjects tested. ${ }^{10}$ The difference of these findings from those of the present study may be explained by direct skin contact of bakers and hairdressers with the persulphates, whereas the chemical workers were protected by gloves. However, a moderate risk of contact dermatitis for chemical workers can be assumed as several subjects had to leave the persulphate workshop because of dermatitis.

It is difficult to draw definite conclusions from cross sectional studies. The persulphate workers were older and had been employed longer than the controls. This may be explained by a selection of the controls, as older workmen are more likely to report persulphate exposure than newly employed subjects simply due to longer occupational exposure time. We cannot exclude that selected populations were examined. However, when the medical records of exworkers from the past 20 years were included in the evaluation, our study gives strong evidence that the allergenic, toxic, or irritant potential of persulphates to cause asthma is low, at least in the chemical industry with pure exposure to ammonium or sodium persulphate in the range of $1 \mathrm{mg} / \mathrm{m}^{3}$.

We acknowledge the technical assistance of Mrs I Santo, Degussa GA, Rheinfelden, Mrs B Schoerling, University
Hospital, Bargmannsheil, Bochum, and Mrs B Aulbach, Hospital, Bargmannsheil, Bochum, and
University Hospital, Frankfurt, Germany.

1 Pepys J, Hutchcroft BJ, Breslin ABX. Asthma due to inhaled chemical agents-persulphate salts and henna in hairdressers. Clin Allergy 1976;6:399-404.

2 Schwaiblmair M, Baur X, Fruhmann G. Bronchial asthma caused by hairbleach in a hairdresser. Dtsch Med Wochenschr 1990;115:695-7. (In German.)

3 Pankow W, Hein H, $v$ Wichert P. Asthma in hairdressers induced by persulfate. Pneumologie 1989;43:173-5. (In German.)

4 Baur X, Fruhmann G, v Liebe V. Occupational asthma and dermatitis after exposure to dusts of persulfate salts in two industrial workers. Respiration 1979;38:144-50. (In German.)

5 Blainey AD, Ollier S, Cundell D, Smith RE, Davies RJ. Occupational asthma in a hairdressing salon. Thorax 1986;41:42-50.

6 Quanjer PH, Tammeling GJ, Cotes JE, Pedersen OF, Peslin R, Yernault JC. Lung volumes and forced ventilatory flows. Report working party standardization of lung tory flows. Report working party standardization of

7 O'Connor G, Sparrow D, Taylor D, Segal M, Weiss S. 'Connor G, Sparrow D, Taylor D, Segal M, Weiss S.
Analysis of dose response curves to methacholine. An Analysis of dose response curves to methacholine. An
approach suitable for population studies. Am Rev Respir Dis 1987;136:1412-7.

8 Forck G. The occurrence and persistence of persulfate allergies. Berufsdermatosen 1968;16:84-92. (In German.)

9 Guerra L, Tosti A, Bardazzi F, Pigatto P, Lisi P, Santucci B, et al. Contact dermatitis in hairdressers: the Italian experience. Contact Dermatitis 1992;26:101-7.

10 Kellett JK, Beck MH. Ammonium persulphate sensitivity in hairdressers. Contact Dermatitis 1985;13:26-8. 